\title{
Information flow and organization of stingless bee foraging
}

\author{
Jacobus C. BIESMEIJER*, E. Judith SLAA \\ Neurobiology and Behavior, Seeley G. Mudd Hall, Cornell University, Ithaca NY 14850, USA
}

(Received 1st August 2003; revised 16 October 2003; accepted 15 December 2003)

\begin{abstract}
Stingless bees (Hymenoptera, Apidae, Meliponini) live in populous permanent colonies and face the same problem as other foraging social insects: how to coordinate the worker's actions and respond to the spatio-temporal uncertainties of food availability in their habitat. Here we review the (social) information used by individual foragers and how organized collective foraging emerges from the individual actions. We also address intra- and interspecific competition for food and the impact of the African honey bee on stingless bee collective foraging.
\end{abstract}

Melipona / Trigona / self-organization / communication / foraging / Africanized honeybee / insect society

\section{INTRODUCTION}

Large social insect colonies lack centralized control yet function as coherent wholes and flexibly adjust their activities in response to environmental challenges. How such a system is organized has become apparent through painstakingly observing the behavior of individually marked individuals (mostly in bees; e.g. Seeley, 1995) or largely anonymous worker groups (mostly in ants; e.g. various chapters in Detrain et al., 1999a). Observation of marked individuals allows one to assess the roles of previous experience and social information on individual decision-making, whereas observation of worker groups focuses on colony-level processes such as allocation of workers over tasks and collective defense and foraging. Only through connecting these two levels, the mechanisms of individual behavior and the patterns that emerge at colony level, can a thorough understanding of the social physiology of insect societies be obtained.

Much of our knowledge of social bees stems from studies performed on a single 'atypical' species, the western honey bee Apis mellifera L. The largest (Michener, 2000) group of social bees, the stingless bees (Apidae, Meliponini) has received much less attention, probably because they inhabit the tropical forest, which traditionally has received less attention from scientists. Only a small fraction of the more than 400 species has been studied in any detail, but already a wide variety of nesting and foraging habits has been discovered. In this paper we review information use by individual foragers and how this relates to organized foraging at colony level. First we describe the various sources of information that foragers may use in individual decisionmaking, then we address the behavioral foraging strategies that stingless bees display, and how these lead to single colony and multi species foraging patterns observed in the field. Finally we analyze the role of different foraging strategies in stingless bee coexistence and the influence of the recent invasion of the African honey bee in the Americas on stingless bee collective foraging.

Note that although we aim at reviewing information on all stingless bees, most studies deal with Neotropical species, some with

\footnotetext{
* Corresponding author: jb329@cornell.edu; ejs53@cornell.edu
} 
Asian species, and very few with African species. Much study has been devoted to recruitment mechanisms of stingless bees, which is reviewed by Nieh in this issue.

\section{INFORMATION SOURCES FOR FORAGERS}

An individual bee makes its behavioral decisions based on information from a variety of sources. We distinguish five major private and social information sources: the individual itself (spontaneous preferences and memory), the nest environment (colony state and nest mates), nest mates in the field, conspecific non-nest mates in the field, and heterospecifics in the field. These extrinsic information sources provide a continuous flow of information to the forager who integrates it with its intrinsic information to make behavioral decisions. We summarize the evidence for information use from each of these sources and its effect on the receiver (Tab. I). In this review we will not address other environmental sources of information used by foragers, e.g. climatic conditions (Lutz, 1931; KleinertGiovannini, 1982; Heard and Hendrikz, 1993), features of flowers, flower patches and other food sources, or the presence of predators (e.g. Craig et al., 1996).

\subsection{Intrinsic information}

Influence of genes on stingless bee behavior is virtually unknown. However, it is safe to assume that stingless bees show spontaneous preferences for some foraging parameters, e.g. flower color and odor, and differ in learning capacity (Pessotti and Lé'Sénéchal, 1981; Biesmeijer and Slaa, unpubl. data) and other aspects of foraging (e.g. scouting tendency, food type selection), as do honey bees. Ranger and O'Donnell (1999) demonstrated a genetic effect on pollen and nectar collecting among Partamona bilineata foragers ( $=$ P. orizabaensis according to Pedro and Camargo, 2003). The acquisition of information must also differ among the species as a result of species-specific differences in their sensory organs (olfactory disk number: Johnson and Howard, 1987; slight differences in photoreceptors: Menzel, 1990), but has rarely been studied.
Memory is another major source of intrinsic information and is used to decide when to start foraging, where to forage, and which flower to visit. This allows bees to inspect known food sources after an interruption (time-place learning; Freitas and Raw, 2000; Biesmeijer and Ermers, 1999; Breed et al., 2002), show flower constancy within patches and over consecutive foraging bouts (Inoue et al., 1985; Biesmeijer and Tóth, 1998; Slaa et al., 1998, 2003a), and discover new patches of learned food plants (Biesmeijer, unpublished data) without needing information from nest mates. As a group experienced foragers probably inspect all profitable food sources from the previous day after an overnight interruption. Together they form the 'joint memory' of the colony (Thierry et al., 1996) and provide the up-to-date information that is the basis of efficient and flexible colony foraging.

Other sources of intrinsic information include development and hormones. In bumble bees larval feeding determines the size of the adult bee, which in turn determines the bee's tendency to forage (Spaethe and Weidenmüller, 2002) and her visual acuity and olfactory perception (Spaethe et al., 2001). Juvenile hormone levels are involved in the switch from nurse bee to forager in honey bees (e.g. Robinson, 1987). None of these factors has received much attention in stingless bee research.

\subsection{Information from nest environment}

Stingless bee colonies consist of several hundreds to tens of thousands of individuals, one or few queens, some virgin queens and males. Virgin queens and males do not participate in foraging [but may visit flowers during their escapades (Kerr, 1994)] and workers collect all food. Therefore, information exchange among the workers is key to colony foraging efficiency and indirectly to colony growth and reproductive success. Social organization is probably largely based on self-organization and individuals use rules of thumb based on information obtained from the nest structures and nest mates to make decisions.

Although the nest environment is structured by activities of the colony's members, it also structures individual behavior. This process is called stigmergy (Grassé, 1959) and plays an 
Table I. Information sources used by stingless bee foragers. Note that not all bee species use all information sources equally (see text for further explanation). Although most species forage for floral nectar and pollen, the information sources also apply to other resources used by stingless bees, such as fruits, meat, resin, mud and water.

\begin{tabular}{|c|c|c|c|c|}
\hline Information source & Information type & Receiver & Effect & References \\
\hline \multicolumn{5}{|l|}{ 1. Intrinsic sources } \\
\hline Genes & $\begin{array}{l}\text { Innate preferences } \\
\text { through gene expression }\end{array}$ & All bees & $\begin{array}{l}\text { Food type selection } \\
\text { (nectar/pollen, flower } \\
\text { color, odor etc.), } \\
\text { learning capacity, } \\
\text { perception, and possibly } \\
\text { scouting tendency }\end{array}$ & $1-4$ \\
\hline \multirow[t]{4}{*}{ Brain } & $\begin{array}{l}\text { Learned information } \\
\text { through memory }\end{array}$ & All bees & & \\
\hline & A. Time of foraging & & Start inspection activity & $5-7$ \\
\hline & B. Place of food source & & $\begin{array}{l}\text { Inspection of known } \\
\text { food source }\end{array}$ & $8-10$ \\
\hline & C. Food type & & $\begin{array}{l}\text { Flower constancy (odor, } \\
\text { color), quality } \\
\text { preference (e.g. nectar } \\
\text { concentration) }\end{array}$ & $11-15$ \\
\hline $\begin{array}{l}\text { Development and } \\
\text { hormones }\end{array}$ & $\begin{array}{l}\text { Preference mediated by } \\
\text { larval food experience } \\
\text { or hormone levels }\end{array}$ & & $? ?$ & Not studied \\
\hline \multicolumn{5}{|l|}{ 2. Nest environment } \\
\hline \multirow[t]{2}{*}{$\begin{array}{l}\text { Colony pollen } \\
\text { reserves }\end{array}$} & $\begin{array}{l}\text { Lack of pollen } \\
\text { availability? } \\
\text { Nurse bees? }\end{array}$ & Pollen foragers & $\begin{array}{l}\text { Probably intensification } \\
\text { of individual foraging } \\
\text { rate }\end{array}$ & 17 \\
\hline & & Non-foragers & $\begin{array}{l}\text { Pollen foraging } \\
\text { preferred to nectar } \\
\text { foraging }\end{array}$ & 17 \\
\hline \multirow[t]{4}{*}{ Successful foragers } & $\begin{array}{l}\text { Behavior (movements, } \\
\text { sounds), trophallaxis, } \\
\text { odor of returnee }\end{array}$ & & & \\
\hline & $\begin{array}{l}\text { A. Location of food } \\
\text { source unknown to } \\
\text { receiver }\end{array}$ & $\begin{array}{l}\text { Naïve and } \\
\text { unemployed foragers }\end{array}$ & $\begin{array}{l}\text { Recruitment to food } \\
\text { source }\end{array}$ & 16 \\
\hline & $\begin{array}{l}\text { B. Odor of known food } \\
\text { source }\end{array}$ & Experienced foragers & $\begin{array}{l}\text { Reactivation to indicated } \\
\text { food source }\end{array}$ & 5,10 \\
\hline & $\begin{array}{l}\text { C. Food source type } \\
\text { (nectar/pollen) }\end{array}$ & Experienced foragers & $\begin{array}{l}\text { Reactivation to similar } \\
\text { food sources }\end{array}$ & 5,10 \\
\hline Waste dumpers & Flight activity & Experienced foragers & Reactivation & 5 \\
\hline $\begin{array}{l}\text { Nectar collectors } \\
\text { that experience a } \\
\text { delay in nectar } \\
\text { unloading }\end{array}$ & $? ?$ & Non-foragers & $\begin{array}{l}\text { Switch to nectar } \\
\text { receiving }\end{array}$ & 30 \\
\hline \multicolumn{5}{|l|}{ 3. Field - nest mates } \\
\hline Successful foragers & $\begin{array}{l}\text { A. Location of food } \\
\text { patch through scent trail } \\
\text { and/or scent marks }\end{array}$ & $\begin{array}{l}\text { Naïve and } \\
\text { unemployed foragers } \\
\text { recruited in the nest }\end{array}$ & $\begin{array}{l}\text { Recruitment to indicated } \\
\text { food source }\end{array}$ & 16 \\
\hline
\end{tabular}


Table I. Continued.

\begin{tabular}{|c|c|c|c|c|}
\hline Information source & Information type & Receiver & Effect & References \\
\hline & $\begin{array}{l}\text { B. Presence of nest mate } \\
\text { on flower }\end{array}$ & $\begin{array}{l}\text { Nest mates foraging } \\
\text { in patch }\end{array}$ & $\begin{array}{l}\text { Local enhancement } \\
\text { (attraction) or local } \\
\text { inhibition (rejection) }\end{array}$ & 18 \\
\hline & $\begin{array}{l}\text { C. Scent marks on } \\
\text { flowers }\end{array}$ & $\begin{array}{l}\text { Nest mates foraging } \\
\text { in patch including the } \\
\text { actor }\end{array}$ & $\begin{array}{l}\text { Selection (or rejection) } \\
\text { of scented flower }\end{array}$ & 16,19 \\
\hline \multicolumn{5}{|c|}{ 4. Field - conspecific non-nest mates } \\
\hline \multirow[t]{2}{*}{ Successful foragers } & $\begin{array}{l}\text { A. Presence of } \\
\text { conspecific non- } \\
\text { nestmate on flower }\end{array}$ & $\begin{array}{l}\text { Non-nest mates } \\
\text { foraging in patch }\end{array}$ & $\begin{array}{l}\text { Local enhancement/ } \\
\text { local inhibition, } \\
\text { aggressive interactions. } \\
\text { Territorial fights may } \\
\text { lead to uniform nest } \\
\text { distribution }\end{array}$ & 20 \\
\hline & $\begin{array}{l}\text { B. Scent marks on } \\
\text { flowers }\end{array}$ & All foragers in patch & $\begin{array}{l}\text { Selection (or rejection) } \\
\text { of scented flower }\end{array}$ & 21 \\
\hline Nest entrance & Visual/olfactory? & $\begin{array}{l}\text { Bees from other } \\
\text { conspecific nests }\end{array}$ & $\begin{array}{l}\text { Attack nest and rob food } \\
\text { and/or wax }\end{array}$ & 22 \\
\hline \multicolumn{5}{|l|}{$\begin{array}{l}\text { 5. Field - } \\
\text { heterospecifics }\end{array}$} \\
\hline \multirow[t]{2}{*}{ Successful foragers } & $\begin{array}{l}\text { A. Presence of } \\
\text { heterospecific on flower }\end{array}$ & $\begin{array}{l}\text { Heterospecifics } \\
\text { foraging in patch }\end{array}$ & $\begin{array}{l}\text { Local enhancement/ } \\
\text { local inhibition, } \\
\text { aggressive interactions }\end{array}$ & $18,23-26$ \\
\hline & $\begin{array}{l}\text { B. Scent marks on } \\
\text { flowers }\end{array}$ & $\begin{array}{l}\text { Heterospecifics } \\
\text { foraging in patch }\end{array}$ & $\begin{array}{l}\text { Selection (or rejection) } \\
\text { of scented flower }\end{array}$ & $2,27-29$ \\
\hline Nest entrance & Visual/olfactory? & $\begin{array}{l}\text { Robber bees near } \\
\text { nest (e.g. } \\
\text { Lestrimelitta, } \\
\text { Cleptotrigona) }\end{array}$ & Organize raid on nest & \\
\hline
\end{tabular}

References: ${ }^{1}$ Pessotti and Lé'Senéchal, 1981; ${ }^{2}$ Johnson, 1987; ${ }^{3}$ Ranger and O'Donnell, 1999; ${ }^{4}$ EJS and JCB, unpubl data; ${ }^{5}$ Biesmeijer et al., 1998; ${ }^{6}$ Biesmeijer and Ermers, $1999 ;{ }^{7}$ Breed et al., 2002; ${ }^{8}$ Lindauer and Kerr, 1958; ${ }^{9}$ Nieh and Roubik, $1995 ;{ }^{10} \mathrm{JCB}$, unpubl. data; ${ }^{11}$ Roubik et al., 1995; ${ }^{12}$ Roubik and Buchmann, 1984; ${ }^{13}$ Biesmeijer et al., 1999b; ${ }^{14}$ Slaa et al., 1998; ${ }^{15}$ Slaa et al., 2003a; ${ }^{16}$ reviewed by Nieh, 2004; ${ }^{17}$ Biesmeijer et al., 1999a; ${ }^{18}$ Slaa et al., 2003b; ${ }^{19}$ Schmidt et al., 2003; ${ }^{20}$ Hubbell and Johnson, 1977; ${ }^{21}$ Villa and Weiss, 1990; ${ }^{22}$ Kerr, 1994; ${ }^{23}$ Schwarz, 1932; ${ }^{24}$ Johnson and Hubbell, 1974; ${ }^{25}$ Howard, 1985; ${ }^{26}$ Nagamitsu and Inoue, 1997; ${ }^{27}$ Kerr et al., $1963 ;{ }^{28}$ Johnson, $1974 ;{ }^{29}$ Johnson, $1983 ;{ }^{30}$ Hart, unpubl. data.

important role in task coordination and the regulation of building activities in many social insects (Theraulaz and Bonabeau, 1995). Stigmergy probably plays an important role in organizing nest and cell building and other activities in stingless bees. It is not known whether the increase in pollen foraging in Melipona beecheii observed after storage pot removal (Biesmeijer et al., 1999a) was induced through stigmergy (direct observation of pollen shortage by (potential) pollen foragers) or through information obtained from nest mates (e.g. nurse bees). Other activities in which stigmergy probably plays a role is in dead bee removal and waste removal.

Returning successful foragers are a rich source of information to nest mates. They may provide detailed information on food source location to naïve foragers (recruitment; Nieh, 2004) and to experienced foragers (reactivation; Biesmeijer and de Vries, 2001). Moreover, experienced foragers from other food sources may use odor and food type cues from a returnee to start or continue foraging at their 
previous source (Biesmeijer et al., 1998). This is evidenced by the observation that the entry of a single pollen-carrying forager into the nest of $M$. costaricensis (all other returnees were captured) may lead to a dramatic increase in outgoing experienced foragers (Biesmeijer et al., 1998). Similarly, injecting scented sugar water into the nest leads to the specific reactivation of foragers with a previously developed association between that scent and any profitable food source (Biesmeijer and Slaa, unpublished data; similar behavior in honey bees: Wenner and Johnson, 1966). Furthermore, returning nectar foragers of $M$. beecheii that experience a long delay before they unload their nectar can apparently induce nest mates to switch to nectar unloading (A. Hart, pers. comm.); an effect similar to that of the tremble dance in Apis mellifera (Seeley et al., 1996). The movements of waste removal bees near the nest entrance can, in absence of information from returning foragers, also activate foragers (Biesmeijer et al., 1998).

\subsection{In the field: social information from nest mates}

The selection of food patches in the field or individual flowers within a patch can be guided by information obtained from nest mates. Finding unknown food patches is facilitated by recruitment communication by means of scent trails (reviewed by Nieh, 2004). Choosing a flower within a patch may be based on scent marks left by nest mates (Villa and Weiss, 1990; Goulson et al., 2001) or on the physical presence of a nest mate on a flower (Slaa et al., 2003b). In both cases the information can be attractive or repellent. Slaa et al. (2003b) observed strong local enhancement (Thorpe, 1956), i.e. selection of the flower occupied by a nest mate, in some species and local inhibition, i.e. avoidance of the flower occupied by a nest mate, in other species. Moreover, in Trigona amalthea the response of arriving bees depended on their previous experience at the flower patch. Naïve foragers landed next to their nest mate on their first arrival. This tendency gradually shifted to complete avoidance of the flower occupied by their nest mate after the fifth visit to the patch. However, to all bees the presence of a nest mate is an attractive visual cue from further away. At closer range the decision whether to land was made (Slaa et al., 2003b).

\subsection{In the field: information from conspecific non-nest mates}

Although stingless bees lack a functional sting, they are by no means defenseless, and aggression of foragers towards non-nest mates has been documented repeatedly (Tab. II; e.g. Schwarz, 1932; Johnson and Hubbell, 1974; Nagamitsu et al., 1999; Slaa, 2003). Aggressive behavior during foraging is species-specific, and seems restricted to species that possess powerful weapons: multiple mandibular teeth in Trigona, caustic acid from mandibular glands in Oxytrigona (Roubik et al., 1987; Roubik, 1992; Michener et al., 1994; Tab. II).

Competition for food is most intense between more similar individuals, i.e. conspecifics from different nests (Johnson, 1974). Diets of conspecific nests are more similar than of heterospecific nests (pollen: Ramalho et al., 1989; Sommeijer et al., 1983; Biesmeijer and van Nieuwstadt, 1997; Nagamitsu et al., 1999; Eltz et al., 2001; nectar: Biesmeijer et al., 1999c). This renders, if foraging ranges overlap, a high probability of encountering a conspecific non-nest mate on a flower. Intraspecific conflict can only take place if bees discriminate nest mates from non-nest mates. Nest mate discrimination has been demonstrated in several Melipona (Breed and Page, 1991; Inoue et al., 1999) and Trigonine species (Suka and Inoue, 1993; Kirchner and Friebe, 1999) and seems common in stingless bees. Fights between non-nest mates usually end in the death of one or both of the bees (Breed and Page, 1991; Biesmeijer and Slaa, pers. obs.) and some fights between conspecific colonies may result in tens to thousands of dead bees (Johnson and Hubbell, 1974; Hubbell and Johnson, 1978). However, in some genera, e.g. Scaptotrigona, bees of multiple colonies scramble peacefully together for nectar or pollen (Johnson, 1974). In Tetragonisca angustula, a non-aggressive species, foragers do not discriminate among the chemical cues left by nest mates and non-nest mates (Villa and Weiss, 1990), but it is unknown whether this is similar for aggressive species. 
Table II. Aggression during foraging in the different stingless bee genera. Note that some species that do not forage aggressively may show aggressive behavior in other contexts, such as nest defense (e.g. Scaptotrigona and Partamona).

\begin{tabular}{|c|c|c|c|}
\hline (sub)Genus & Aggressive foraging & Non-aggressive foraging & Reference \\
\hline Melipona & & $\begin{array}{l}\text { costaricensis }( \pm) \text { (prev. fasciata), } \\
\text { fulva }\end{array}$ & $\begin{array}{l}1,2 \\
12\end{array}$ \\
\hline Cephalotrigona & & capitata & 1 \\
\hline Homotrigona & fimbriata & & 3 \\
\hline Hypotrigona & & spp. & 4 \\
\hline Lepidotrigona & & ventralis & 3 \\
\hline Liotrigona & & spp. & 4 \\
\hline Nannotrigona & & testaceicornis $( \pm)$ & 1,5 \\
\hline Noguerapis & & mirandula & 2 \\
\hline Oxytrigona & $\begin{array}{l}\text { mellicolor, } \\
\text { obscura }\end{array}$ & & $\begin{array}{l}1 \\
12\end{array}$ \\
\hline Partamona & & $\begin{array}{l}\text { aff. cupira }( \pm), \\
\text { testacea }\end{array}$ & $\begin{array}{l}1,2 \\
12\end{array}$ \\
\hline Plebeia & & $\begin{array}{l}\text { frontalis, } \\
\text { jatiformis }\end{array}$ & $\begin{array}{l}1,5 \\
2\end{array}$ \\
\hline Scaptotrigona & & $\begin{array}{l}\text { pectoralis, } \\
\text { mexicana }\end{array}$ & $\begin{array}{l}1,6 \\
7\end{array}$ \\
\hline Scaura & & latitarsus & 7 \\
\hline Tetragona & clavipes & dorsalis & $\begin{array}{l}1 \\
12\end{array}$ \\
\hline Tetragonisca & & angustula & 1 \\
\hline Tetragonula & melina $( \pm)$ & $\begin{array}{l}\text { melanocephala, } \\
\text { leaviceps }\end{array}$ & $\begin{array}{l}3 \\
3\end{array}$ \\
\hline Tetrigona & apicalis & & 3 \\
\hline Trigona & $\begin{array}{l}\text { corvina, } \\
\text { cilipes, } \\
\text { fuscipennis, } \\
\text { hyalinata, } \\
\text { pallens, } \\
\text { amalthea, } \\
\text { fulviventris }( \pm), \\
\text { canifrons } \\
\text { iridipennis } \\
\text { williana } \\
\text { spinipes }\end{array}$ & & $\begin{array}{l}1,6,7 \\
12 \\
5,6,8 \\
6,9 \\
6 \\
1,2,5-7 \\
1,2,5,8 \\
2 \\
10 \\
5,11-13 \\
9\end{array}$ \\
\hline Trigonisca & & buyssoni & 5 \\
\hline
\end{tabular}

References: ${ }^{1}$ Slaa, 2003; ${ }^{2}$ Howard, 1985; ${ }^{3}$ Nagamitsu and Inoue, 1997; ${ }^{4}$ Darchen, 1972, cited in Hubbell and Johnson, 1977; ${ }^{5}$ Hubbell and Johnson, 1978; ${ }^{6}$ Johnson, 1983; ${ }^{7}$ Johnson and Hubbell, 1974; ${ }^{8}$ Johnson and Hubbell, 1975; ${ }^{9}$ Kerr et al., 1981; ${ }^{10}$ Koeniger and Vorwohl, 1979; ${ }^{11}$ Schwarz, 1932; ${ }^{12}$ Roubik, 1980;

13Johnson, 1981. 


\subsection{In the field: information from heterospecifics}

Because the stingless bees of a community overlap highly in foraging range (e.g. Hubbell and Johnson, 1977; Roubik, 1983b; Eltz et al., 2002; Slaa, 2003), encounters between heterospecifics are common. Reactions to a heterospecific vary widely from avoidance to attack, depending on the species combination (Slaa et al., 2003b). Aggressive species are sometimes attracted towards a heterospecific, generally leading to the departure of the resident bee. However, avoidance of a heterospecific seems much more common, and avoidance behaviour is accurately predicted by relative body size and aggressiveness of the two species: non-aggressive species avoid aggressive species and smaller species generally avoid larger species (Slaa et al., 2003b).

Besides the physical presence of a bee, foragers may also pick up scent cues from heterospecifics. Evidence exists for both attraction to and avoidance of heterospecific scent marks. Johnson (1974) found that pheromones of an aggressive species on a food source repel a less aggressive species. Experiments by Kerr et al. (1963) suggest that Scaptotrigona xanthotricha can follow the scent trails left by $S$. postica, although this hetero-specific trail following was non-reciprocal. In addition, the dominant $T$. amalthea seems to exploit the capacity of the less aggressive $T$. fulviventris to quickly find new food sources by attraction to its scent marks (Johnson, 1983, 1987).

Although most species collect their food from sources in the field (i.e. flowers, carcasses, fruits, etc.), some species are specialized in attacking other stingless bee nests for the collection of food. Such obligate robbers (belonging to the genera Lestrimelitta and Cleptotrigona) probably use visual and/or olfactory cues to find nest entrances of potential victim colonies. Such raids may also occasionally occur in species that normally collect food from sources in the field (Roubik, 1989; H. de Jong, pers. comm.).

\section{FORAGING ORGANIZATION OF A SINGLE COLONY}

The use of information from the various sources described above leads to a wide vari- ety of solitary and social foraging behaviors. Whereas stingless bees, like honey bees, are highly social concerning nest activities, foraging is not necessarily a group activity. This is in fact also similar to the honey bee, where the waggle dance is used only for excellent food sources (rare and unpredictable in nature) and where in dearth periods many foragers search independently for food (Seeley, 1983; Seeley and Visscher, 1988; Biesmeijer, unpublished data).

Some species are always solitary foragers, i.e. they never recruit nest mates to food sources, others are obligate group foragers, and yet others are facultative group foragers (Johnson, 1983). The solitary foragers use mainly intrinsic information to exploit food sources, but may use odors from foragers returning to the nest (Lindauer and Kerr, 1958), scent marks left by others on flowers and the presence of nest mates on resources as cues. The group foragers may use any information source mentioned above and in Table I to make foraging decisions.

The social physiology of stingless bee colonies is probably as advanced as that of honey bees (Seeley, 1995). So far they have been shown to have coordinated nest defense (e.g. Lindauer, 1957) and nest building, division of labor (e.g. Sommeijer et al., 1982; Sommeijer, 1984), task partitioning of nectar foraging (Sommeijer et al., 1985; Hart and Ratnieks, 2002), adjustment of worker behavior and worker allocation in response to the removal of nectar reserves (Kolmes and Sommeijer, 1992a, b), the ability to counter deficits in pollen reserves (Biesmeijer et al., 1999a) and to select the best of a series of food sources (Biesmeijer and Ermers, 1999).

The collective foraging patterns emerge from the multitude of activities of individual foragers that make foraging decisions based on intrinsic and other information they have acquired. The life of a stingless bee (or other social insect) forager looks more or less like this (Biesmeijer and de Vries, 2001; Seeley, 1995): each bee starts as a naïve forager, and can then either become a scout (if only intrinsic information is used) or a recruit (if information from nest mates stimulates the start of foraging). After having found a food source she is an employed forager and tends to revisit the food source. At the end of the day or 
foraging period she becomes temporarily unemployed. Next she can either revisit her previous food source as an inspector (based on intrinsic information from previous foraging) or as a reactivated forager (if nest mates provide information about her previous food source) or search for a new food source as a scout or recruit. After finding a rich food source she can (in most species) provide nest mates with information on the location of that food source and initiate recruitment.

Recruitment communication directs the allocation of naïve and temporarily unemployed foragers over food sources. However, the majority of the foragers at any time have some previous experience and much of the colony's efficiency in exploiting food sources is a result of individual foragers responding to the changes in their direct environment. For example, new food sources may be found by special scouts, but also by experienced bees that start searching after their food sources dried up and by errand recruits (Biesmeijer, unpublished data). Also, the choice of a colony for the richest food source is simply a result of bees that decide to start, continue or stop foraging based on previous experience at their food source and not of any cross-referencing procedure (Biesmeijer and Ermers, 1999). This again is similar in honey bees where the nectar receiving bees are the only link between the various nectar sources exploited by different groups of bees (Seeley, 1995). The species-specific spatial pattern of food source exploitation is also a result of individual bees showing either local enhancement, which leads to clumped group foraging, or local inhibition, which leads to dispersed group foraging (Slaa et al., 2003b).

\section{FORAGING STRATEGIES IN HETEROSPECIFIC INTERACTIONS}

Based on years of behavioral observation of interactions among Costa Rican Trigona bees, Johnson (1983) recognized four solitary and four group foraging strategies.

The solitary foraging strategies are: 1 . Avoidance, a bee chooses not to forage near another bee or bees (i.e. local inhibition). Avoidance occurs on small, scattered, slow- renewing sources and as a response to bigger, more aggressive residents. 2. Displacement, an arriving bee causes the departure of a (generally smaller) resident with or without aggressive behavioral interaction. 3. Gleaning, a (generally small) bee collects the leftovers after the peak of attractiveness or other visitors have passed. 4. Insinuation, a (small) bee nervously but persistently collects from a source occupied by aggressive bees.

The group foraging strategies distinguished by Johnson (1983) are: 1. Scramble group foraging, also referred to as exploitation competition, where each bee collects food (and recruits) as quickly as possible without physical interference with other bees. 2. Bustling, the hyperactive foraging movements of bees discourages other bees to forage at the same flowers. 3. Extirpation, where after rapid recruitment of nest mates to a rich food source the residents are chased off aggressively. 4. Opportunism, bees usually forage solitary but may rapidly recruit nest mates if an exceptionally good food source is found. They continue till stronger rivals extirpate them from the flowers.

Johnson's eight foraging strategies are neither species-specific nor complementary. Furthermore, although scramble is defined as a group foraging strategy, a single forager that does not show avoidance or displacement but peacefully feeds with other bees is also a scrambler (and cannot be put in any other category). Another way of approaching stingless bee foraging strategies in relation to heterospecifics would be to describe them in terms of three foraging parameters: recruitment ability (solitary or group foraging), degree of local enhancement towards heterospecifics (attraction or avoidance), and competitive ability (aggressive or not). Table III shows that most of Johnson's strategies correspond to a specific combination of these three parameters. Only avoidance and gleaning correspond to the same combination of bees that do not recruit, show local inhibition towards heterospecifics and are competitively weak. The only difference is that gleaners stick around till the stronger rivals have gone and then start food collecting, whereas avoiders leave without collecting food. In addition, opportunists form a difficult category. When not recruiting they may show avoidance, displacement or 
Table III. Social foraging strategies of stingless bees defined by Johnson (1983) and their relation with three major foraging parameters: recruitment ability, local enhancement in heterospecific encounters, and individual aggressiveness.

\begin{tabular}{lccc}
\hline Solitary foraging & Recruitment & Local enhancement & Aggressive behavior \\
\hline Avoidance & No & No & No \\
Displacement & No & Yes & Yes \\
Gleaning & No & No & No \\
Insinuation & No & Yes & No \\
\hline Social foraging & & & No \\
\hline Scrambling & Yes & Yes & No \\
Bustling & Yes & No & Yes \\
Extirpation & Yes & Yes & No \\
Opportunism & Yes/No & Yes/No & \\
\hline
\end{tabular}

individual scrambling, but when recruiting they may show local enhancement or inhibition towards nest mates and local inhibition towards stronger rivals.

Honey bees can be categorized as scramblers both when foraging solitary among other bees and when foraging in groups. Because of their large size, however, they may cause displacement and avoidance of smaller stingless bees including aggressive species (Roubik, 1980; Slaa, 2003).

\section{COEXISTENCE OF SPECIES WITH DIFFERENT FORAGING STRATEGIES}

Stingless bees are very successful in most tropical habitats where about 1 of every 2 bees seen on flowers is a stingless bee (Heithaus, 1979; Roubik, 1989) and up to several dozen species may occur sympatrically (Roubik, 1989; Slaa, 2003). Stingless bee abundance seems more dependent on food sources than on nest site availability (Hubbell and Johnson, 1977; Eltz et al., 2002), and diet overlap, in terms of food plant species used, is generally considerable (Roubik et al., 1986; Ramalho et al., 1990; Eltz et al., 2001). However, Roubik and Moreno (2000) found that three species of stingless bees were both generalists (using the same key species) and specialists (using minor and major species little used by others) and Nieuwstadt et al. (1997) found that a few plant species make up the bulk of the pollen diet. Their generalist foraging strategy and the overlap in resource use has led to the hypothesis that coexistence of stingless bees largely stems from subtle partitioning of food sources based on diversity in timing, persistence, renewal rate, and spatial dispersion of their limited food sources (Hubbell and Johnson, 1978).

The foraging strategies observed at present have evolved from a basic plan. Each is geared towards exploitation of specific food sources by putting differential weight on the major information sources and foraging parameters, e.g. recruitment precision and intensity, aggressiveness, independent search, and local enhancement. The mass-recruiting aggressive bees, e.g. several Trigona and Oxytrigona, are high-density specialists. They form dense forager groups through local enhancement, possess powerful weapons (teeth or burning acid; Slaa, 2003) to attack everything at and near the food and so monopolize clumped food sources. They are, however, not very good at finding new food sources (Nagamitsu et al., 1999; Slaa, 2003). This is the trade-off for low independent scouting ability (all bees are needed as recruits) and strong local enhancement (no neighboring food patches are found). The mass-recruiting non-aggressive bees, e.g. Scaptotrigona, Partamona and Apis, are also high-density specialists. They do not show strong local enhancement and quickly find food patches near the one discovered by the scout bee (Nagamitsu et al., 1999; Slaa, 2003). In this way they can keep one step ahead of the 
aggressive group foragers and display shortterm use of rich and clumped food sources. The poorly recruiting species probably provide nest mates with some general indication of food odor or location that can guide their largely independent search (Lindauer and Kerr, 1958, 1960; similar in bumble bees: Dornhaus and Chittka, 2001). They may show local enhancement (e.g. Tetragonisca angustula; Slaa et al., 2003b) or indifference to the presence of nest mates (e.g. Tetragona dorsalis; Slaa et al., 2003b). Occasionally they persist as scramblers at high-density food sources, but generally use low-density food sources (Hubbell and Johnson, 1978). Yet another group of species, e.g. Trigona fulviventris and T. amalthea, uses recruitment occasionally, but commonly forage solitarily at low-density food sources (facultative group foragers; Hubbell and Johnson, 1978; Slaa, 2003). They are strong individual competitors that show local inhibition towards nest mates (Slaa et al., 2003b), but carefully single out weaker rivals for attack. In this way they spread out over food sources and may monopolize high-density food patches till the arrival of extirpators or dominate low-density patches for longer periods (Johnson, 1975).

\section{COEXISTENCE WITH THE AFRICAN HONEY BEE}

Since its introduction into Brazil in 1956 the African honey bee, Apis mellifera scutellata Lepeletier has invaded every corner of tropical and subtropical America including stingless bee territory. Many studies show that the presence of the African honey bee leads to a decrease in stingless bee foraging at flower patches (e.g. Roubik, 1978, 1989) and diminished colony foraging peaks in various species (Roubik et al., 1986), but not to lower colony food storage or brood production (Roubik, 1983a). In Panama, stingless bee populations do not seem affected by African honey bees even 10 years after their arrival (Roubik and Wolda, 2001).

Honey bees are scramble competitors and larger than stingless bees. This prevents aggressive Trigona from taking over a food source occupied by multiple African honey bees, but other scramble foragers, e.g.
Melipona, Partamona, Scaptotrigona, and smaller stingless bees, may share the food source with African honey bees (Roubik, 1980). In this way African honey bees can make rich food sources accessible to stingless bee scramblers that would otherwise be displaced by aggressive group foragers. Other aggressive stingless bees, e.g. Trigona pallens and Tetragona clavipes, may share a rich food source with African honey bees by monopolizing part of it (Roubik, 1980). The impact of African honey bees on stingless bee foraging thus depends on the foraging strategy used by the stingless bee species.

\section{CONCLUDING THOUGHTS}

Stingless bee foraging is, as is foraging in most social insects, largely self-organized. There is no omniscient manager that integrates all information and issues orders to the subunits. This does not mean, however, that individual foragers lack sophisticated cognitive abilities. They can learn and memorize many things and may share some advanced cognitive features, e.g. concept abstraction (Giurfa et al., 1996, 1999), with honey bees. For foraging, some species (solitary foragers) rely largely on individual decision making in the field. This is similar to bumble bee foraging (Dornhaus and Chittka, 2004). On the other extreme are the obligate group foragers that largely rely on collective decision-making. However, here it is not 'blind' trail following as in some ants (e.g. Detrain et al., 1999b), since individuals that loose track can rely on intrinsic and field information to locate other food sources (Slaa, 2003) or return home. The facultative group foragers are intermediate. They normally rely on individual decisionmaking, but in 'recruitment mode' rely heavily on collective decision-making.

The species-specific balance between individual and collective decision-making determines the foraging niche of each species. The coexistence of multiple species with different foraging strategies indicates that the various strategies are complementary in the way they extract food from their ever-changing habitat. It seems therefore not justified to refer to some strategies as primitive and others (e.g. mass-recruiting strategies) as advanced. 
The aggressive group foraging strategy has received most attention simply because it is spectacular and easily observed at an artificial nectar feeder. However, it is only one aspect of the rich variety of foraging behaviors that stingless bees perform.

Résumé - Flux d'information et organisation du butinage chez les abeilles sans aiguillon. Les abeilles sans aiguillon (Hymenoptera, Apidae, Meliponini) vivent en colonies pérennes populeuses et sont confrontées aux mêmes problèmes que les autres insectes sociaux qui butinent: comment coordonner l'action des ouvrières et répondre aux incertitudes spatio-temporelles de la disponibilité en nourriture dans leur habitat. Nous passons en revue les informations sociales utilisées individuellement par les butineuses et examinons comment un butinage collectif organisé émerge des actions individuelles. Nous traitons aussi de la compétition intra- et interspécifique pour la nourriture et de l'impact de l'Abeille africanisée sur le butinage collectif des abeilles sans aiguillon.

Le tableau I résume les principales sources d'informations que peuvent utiliser les butineuses des abeilles sans aiguillon. Elles se répartissent en informations intrinsèques (par ex., les préférences innées dues à l'expression des gènes, à la mémoire, aux taux d'hormones) et les informations extrinsèques. Celles-ci incluent les informations en provenance du nid (membres de la colonie, structure du nid) et celles provenant de l'extérieur par l'intermédiaire des membres de la colonie, des individus de la même espèce et des autres espèces. Les membres de la colonie prennent à titre individuel leurs décisions en se basant sur l'intégration des informations intrinsèques et extrinsèques et la multitude des activités individuelles aboutit à un comportement collectif efficace. La physiologie sociale des colonies d'abeilles sans aiguillon est aussi avancée que celle des abeilles mellifères et comprend la construction et la défense du nid par coopération, le butinage collectif et le choix de la meilleur source de nourriture.

Dans la plupart des habitats tropicaux plusieurs espèces d'abeilles sans aiguillon sont présentes de façon sympatrique et entrent en compétition pour la nourriture. La coexistence est rendue possible par le développement d'une diversification des stratégies individuelles et sociales de butinage. On dénombre quatre stratégies individuelles : les butineuses s'évitent, se déplacent, glanent et se faufilent, et quatre stratégies sociales: elles se bousculent, s'agitent, s'extirpent et font preuve d'opportunisme. Ces huit stratégies reposent sur des différences dans les paramètres de butinage (Tab. III) : capacité de recrutement (butinage solitaire ou recrutement jusqu'à un certain degré), augmentation locale des membres de la colonie (attraction, indifférence ou évitement) et capacité compétitive individuelle (agressivité ou non ; Tab. II). Chacune de ces stratégies de butinage propre à chaque espèce semble conçue pour exploiter un sous-ensemble spécifique (dans l'espace, le temps ou l'identité floristique) des sources potentielles de nourriture et les diverses stratégies sont grandement complémentaires.

Le monde des abeilles sans aiguillon néotropicales a récemment été occupé par des milliers de colonies d'abeilles africanisées avec lesquelles elles partagent désormais de nombreuses sources de nourriture. Les pics de butinage ont diminué et le déplacement a régulièrement lieu, mais l'impact des abeilles africanisées sur la population d'abeilles sans aiguillon n'est pas encore entièrement comprise.

\section{Melipona / Trigona / autoorganisation / commu- nication / butinage /abeille africanisée /société d'insectes}

Zusammenfassung - Informationsübertragung und Organisation des Sammelverhaltens bei Stachellosen Bienen. Stachellose Bienen (Hymenoptera, Apidae, Meliponini) leben in mitgliederstarken dauerhaften Völkern und haben das gleiche Problem wie alle sozialen Insekten beim Futter sammeln: Koordination der Aktionen der Arbeiterinnen und Reaktion auf räumlich - zeitliche Unsicherheiten im Futterangebot ihres Umfelds. Wir geben hier einen Überblick über die (soziale) Information, die von individuellen Sammelbienen benutzt werden und wie ein kollektives Sammeln aus den Aktionen von Einzeltieren hervorgeht. Wir sprechen auch über die intra- und interspezifische Konkurrenz für Nahrung und die Auswirkung von Afrikanisierten Honigbienen auf das kollektive Sammeln bei Stachellose Bienen.

Die wichtigsten Informationsquellen, die von Sammlerinnen der Stachellose Bienen genutzt werden können, sind in Tabelle I zusammengefasst und basieren auf in der Biene liegender Information (z.B. angeborene Vorzüge auf Grund genetischer Expression, Gedächtnis, Hormonspiegel) und von außen wirkender Information. Letzteres umfasst Informationen innerhalb des Nestes (Nestgenossinnen und Neststruktur) und aus dem Umfeld des Nestes durch Nestgenossinnen, durch artgleiche Nicht - Nestgenossinnen und Bienen anderer Arten. Einzelne Volksmitglieder entscheiden sich im Verhalten auf Grund einer Integration von inneren und äußeren Informationen, und die Vielzahl von individuellen Aktivitäten führt zu einem effektivkollektiven Verhalten. Die soziale Physiologie der Völker der Stachellosen Bienen ist genauso weit fortgeschritten wie das der Honigbienen und schließt gemeinsamen Nestbau und Verteidigung, kollektives Sammeln von Nahrung und Auswahl der besten Nahrungsquelle ein.

In vielen tropischen Lebensräumen kommen mehrere Arten der Stachellose Bienen sympatrisch 
vor und konkurrieren um die Nahrung. Die Coexistenz ist durch die Entwicklung einer Mannigfaltigkeit der individuellen und der sozialen Sammelstrategie möglich. Diese bestehen aus 4 individuellen Strategien: Vermeidung, Verlagerung, Nachlese und sich Einschleichen; und 4 Gruppenstrategien: Drängeln, Vorpreschen, Vernichtung und Opportunismus. Diese 8 Strategien beruhen auf Unterschieden von 3 Parametern (Tab. III): Fähigkeit zur Rekrutierung, (solitäres Sammeln oder Rekrutierung bis zu einem gewissen Grad), lokale Verstärkung von Nestgenossinnen (Attraktion, Nichtbeachtung oder Vermeidung) und individuelle Fähigkeiten bei der Konkurrenz (aggressiv oder nicht; Tab. II). Jede dieser artspezifischen Sammelstrategien scheint an die Nutzung von spezifischen Teileigenschaften (in Raum, Zeit oder Blütenidentität) von möglichen Nahrungsquellen angepasst zu sein und die verschiedenen Strategien ergänzen sich großenteils.

Der Lebensraum der neotropen Stachellosen Bienen ist in der letzten Zeit von tausenden Völkern der Afrikanisierten Honigbienen bewohnt, mit denen sie jetzt viele ihrer Nahrungsquellen teilen müssen. Spitzenernten beim Sammeln sind seltener geworden und Verdrängungen kommen regelmäßig vor, aber die Auswirkung der Afrikanisierten Honigbienen auf die Population der Stachellosen Bienen ist immer noch nicht vollständig klar.

\section{Melipona / Trigona / Selbstorganisation / Kommunikation / Sammeln / Afrikanisierte Honigbiene / Insektenvolk}

\section{REFERENCES}

Biesmeijer J.C., van Nieuwstadt M.G.L. (1997) Colony foraging patterns of stingless bees in Costa Rica, with special reference to pollen, in: The Organisation of Foraging in Stingless Bees of the Genus Melipona, dissertation Utrecht University, The Netherlands, pp. 35-57.

Biesmeijer J.C., Tóth E. (1998) Individual foraging, activity level and longevity in the stingless bee Melipona beecheii in Costa Rica (Hymenoptera, Apidae, Meliponinae), Insectes Soc. 45, 427443.

Biesmeijer J.C., de Vries H. (2001) Exploration and exploitation of food sources by social insect colonies: a revision of the scout-recruit concept, Behav. Ecol. Sociobiol. 49, 89-99.

Biesmeijer J.C., Ermers M.C.W. (1999) Social foraging in stingless bees: how a $M$. fasciata colony chooses between nectar sources, Behav. Ecol. Sociobiol. 46, 129-140.

Biesmeijer J.C., van Nieuwstadt M.G.L., Lukács S., Sommeijer M.J. (1998) The role of internal and external information on foraging decisions of Melipona workers (Hym.; Meliponinae), Behav. Ecol. Sociobiol. 42, 107-116.
Biesmeijer J.C., Born M., Lukács S., Sommeijer M.J. (1999a) The response of M. beecheii experimental pollen stress, worker loss and different levels of information input, J. Apic. Res. 38, 29-37.

Biesmeijer J.C., Richter J.A.P., Smeets M., Sommeijer M.J. (1999b) Niche differentiation in nectar-collecting stingless bees: the influence of morphology, floral choice and interference competition, Ecol. Entomol. 24, 380-388.

Biesmeijer J.C., Smeets M., Richter J.A.P., Sommeijer M.J. (1999c) Nectar foraging by stingless bees in Costa Rica: botanical and climatological influences on sugar concentration of nectar collected by Melipona, Apidologie 30, 43-55.

Breed M.D., Page R.E. Jr. (1991) Intra- and interspecific nestmate recognition in Melipona workers (Hymenoptera: Apidae), J. Insect Behav. 4, 463-469.

Breed M.D., Stocker E.M., Baumgartner L.K., Vargas S.A. (2002) Time-place learning and the ecology of recruitment in a stingless bee, Trigona amalthea (Hymenoptera, Apidae), Apidologie $33,1-8$.

Craig C.L., Weber R.S., Bernard G.D. (1996) Evolution of predator-prey systems: Spider foraging plasticity in response to the visual ecology of prey, Am. Nat. 147, 205-229.

Darchen R. (1972) Écologie de quelques trigones (Trigona sp.) de la savane de Lamto (Côte d'Ivoire), Apidologie 3, 341-367.

Detrain C., Deneubourg J.L., Pasteels J.M. (1999a) Information processing in social insects, Birkhäuser, Basel.

Detrain C., Deneubourg J.L., Pasteels J.M. (1999b) Decision-making in foraging by social insects, in: Detrain C., Deneubourg J.L., Pasteels J.M. (Eds.), Information processing in social insects, Birkhäuser, Basel, pp. 331-354.

Dornhaus A., Chittka L. (2001) Food alert in bumblebees (Bombus terrestris): possible mechanisms and evolutionary implications, Behav. Ecol. Sociobiol. 50, 570-576.

Dornhaus A., Chittka L. (2004) Information flow and regulation of foraging activity in bumble bees (Bombus spp.), Apidologie 35, 183-192.

Eltz T., Brühl C.A., van der Kaars S., Chey V.K., Linsenmair K.E. (2001) Pollen foraging and resource partitioning of stingless bees in relation to flowering dynamics in a Southeast Asian tropical rainforest, Insectes Soc. 48, 273-279.

Eltz T., Brühl C.A., van der Kaars S., Linsenmair K.E. (2002) Determinants of stingless bee nest density in lowland dipterocarp forests of Sabah, Malaysia, Oecologia 131, 27-34.

Freitas R.I.P., Raw A. (2000) The perception of time by foraging workers of stingless bees (Hymenoptera: Apidae, Meliponini), in: Proc. 6th Int. Conf. on Apiculture in Tropical Climates, Costa Rica, IBRA, Cardiff, pp. 101-105. 
Giurfa M., Eichmann B., Menzel R. (1996) Symmetry perception in an insect, Nature 382, 458-461.

Giurfa M., Zhang S., Jennet A., Menzel R., Srinivasan M.V. (1999) The concepts of 'sameness' and 'difference' in an insect, Nature 410, 930-933.

Goulson D., Chapman J.W., Hughes W.O.H. (2001) Discrimination of unrewarded flowers by bees; direct detection of rewards and use of repellent scent marks, J. Insect Behav. 14, 669-678.

Grassé P.P. (1959) La reconstruction du nid et les coordinations interindividuelles chez Bellicositermes natalensis et Cubitermes sp. La théorie de la stigmergie. Essais d'interprétation du comportement des termites constructeurs, Insectes Soc. 6, 41-84.

Hart A.G., Ratnieks F.L.W. (2002) Task-partitioned nectar transfer in stingless bees: work organization in a phylogenetic context, Ecol. Entomol. 27, 163-168.

Heard and Hendrikz (1993) Factors influencing flight activity of colonies of the stingless bee Trigona carbonaria, Aust. J. Zool. 41, 343-353.

Heithaus E.R. (1979) Community structure of neotropical flower visiting bees and wasps: diversity and phenology, Ecology 60, 190-202.

Howard J.J. (1985) Observations on resin collecting by six interacting species of stingless bees (Apidae: Meliponinae), J. Kans. Entomol. Soc. 58, 337-345.

Hubbell S.P., Johnson L.K. (1977) Competition and nest spacing in a tropical stingless bee community, Ecology 58, 949-963.

Hubbell S.P., Johnson L.K. (1978) Comparative foraging behavior of six stingless bee species exploiting a standardized resource, Ecology 59, 1123-1136.

Inoue T., Salmah S., Abbas I., Yusuf E. (1985) Foraging behaviour of individual workers and foraging dynamics of colonies of three Sumatran stingless bees, Res. Popul. Ecol. 27, 373-392.

Inoue T., Roubik D.W., Suka T. (1999) Nestmate recognition in the stingless bee Melipona panamica (Apidae, Meliponini), Insectes Soc. 46, 208-218.

Johnson L.K. (1974) The Role of Agonistic Behavior in the Foraging Strategies of Trigona Bees, Doctoral thesis, University of California, Berkeley, California.

Johnson L.K. (1975) Contrasting foraging strategies and coexistence of two bee species on a single resource, Ecology 56, 1398-1406.

Johnson L.K. (1981) Effect of flower clumping on defense of artificial flowers by aggressive stingless bees, Biotropica 13, 151-157.

Johnson L.K. (1983) Foraging strategies and the structure of stingless bee communities in Costa Rica, in: Jaisson P. (Ed.), Social Insects in the Tropics 2, Université Paris-Nord, Paris, pp. 31-58.

Johnson L.K. (1987) Communication of food source location by the stingless bee Trigona fulviventris, in: Eder J., Rembold H. (Eds.), Chemistry and
Biology of Social Insects, Verlag J. Peperny, München, pp. 698-699.

Johnson L.K., Howard J.J. (1987) Olfactory disc number in bees of different sizes and ways of life (Apidae: Meliponinae), J. Kans. Entomol. Soc. 60, 380-388.

Johnson L.K., Hubbell S.P. (1974) Aggression and competition among stingless bees: Field studies, Ecology 55, 120-127.

Johnson L.K., Hubbell S.P. (1975) Contrasting foraging strategies and coexistence of two bee species on a single resource, Ecology 56, 13981406.

Kerr W.E. (1994) Communication among Melipona workers (Hymenoptera: Apidae), J. Insect Behav. 7, 123-128.

Kerr W.E., Ferreira A., Simões de Mattos N. (1963) Communication among stingless bees - Additional data (Hymenoptera: Apidae), J. N.Y. Entomol. Soc. 71, 80-90.

Kerr W.E., Blum M., Fales H.M. (1981) Communication of food source between workers of Trigona (Trigona) spinipes, Rev. Bras. Biol. 41, 619-623.

Kirchner W.H., Friebe R. (1999) Nestmate recognition in the African stingless bee Hypotrigona gribodoi Magretti (Hymenoptera: Apidae), Apidologie 30, 293-298.

Kleinert-Giovannini A. (1982) The influence of climatic factors on flight activity of Plebeia emerina Friese (Hymenoptera, Apidae, Meliponinae) in winter, Rev. Bras. Entomol. 26, 1-13.

Koeniger N., Vorwohl G. (1979) Competition for food among four sympatric species of Apini in Sri Lanka (Apis dorsata, Apis cerana, Apis florea and Trigona iridipennis), J. Apic. Res. 18, 95-109.

Kolmes S.A., Sommeijer M.J. (1992a) Ergonomics in stingless bees: changes in intranidal behaviour after partial removal of storage pots and honey in Melipona favosa (Hym. Apidae, Meliponinae), Insectes Soc. 39, 215-232.

Kolmes S.A., Sommeijer M.J. (1992b) A quantitative analysis of behavioral specialization among worker stingless bees (Melipona favosa F.) performing hive duties (Hymenoptera, Apidae), J. Kans. Entomol. Soc. 65, 421-430.

Lindauer M. (1957) Zur Biologie der stachellosen Bienen: ihre Abwehrmethoden. Ber. Wanderversamml., Dtsch. Entomol. 8, 71-78.

Lindauer M., Kerr W.E. (1958) Die gegenseitige Verständigung bei den stachellosen Bienen, Z . Vergl. Physiol. 41, 405-434.

Lindauer M., Kerr W.E. (1960) Communication between the workers of stingless bees, Bee World $41,29-41 ; 65-71$.

Lutz F.E. (1931) Light as a factor in controlling the start of daily activity of a wren and stingless bees, Am. Mus. Novit. 468, 1-9.

Menzel R. (1990) Colour vision in flower visiting insects, Jülich, Berlin. 
Michener C.D. (2000) The bees of the world, Johns Hopkins university Press, Baltimore Maryland.

Michener C.D., McGinley R.J., Danforth B.N. (1994) The Bee Genera of North and Central America, Smithsonian Institution Press, Washington.

Nagamitsu T., Inoue T. (1997) Aggressive foraging of social bees as a mechanism of floral resource partitioning in an Asian tropical rainforest, Oecologia 110, 432-439.

Nagamitsu T., Momose K., Inoue T., Roubik D.W. (1999) Preference in flower visits and partitioning in pollen diets of stingless bees in an Asian tropical rain forest, Res. Popul. Ecol. 41, 195202.

Nieh J.C., Roubik D.W. (1995) A stingless bee (Melipona panamica) indicates food location without using a scent trail, Behav. Ecol. Sociobiol. 37, 63-70.

Nieh J.C. (2004) Recruitment communication in stingless bees (Hymenoptera, Apidae, Meliponini), Apidologie 35, 159-182.

Nieuwstadt M.G.L. van, Sanchez L.A., Biesmeijer J.C., Arce H.G., Sommeijer M.J. (1997) Foraging behavior of stingless bees: are their diets really so diverse? in: Mardan M. et al. (Eds.), Proc. Int. Conf. Tropical Bees and the Environment, Beenet Asia, Univ. Pertanian, Malaysia, pp. 100-110.

Pedro S.R.M., Camargo J.F.M. (2003) Meliponini neotropicais: O genero Partamona Schwarz, 1939 (Hymenoptera, Apidae), Rev. Bras. Entomol. 47, $1-117$.

Pessotti I., Lé’Sénéchal A.M. (1981) Aprendizagem em abelhas. I- Discriminação simples em onze espécies, Acta Amaz. 11, 653-658.

Ramalho M., Kleinert-Giovannini A., ImperatrizFonseca V.L. (1989) Utilization of floral resources by species of Melipona (Apidae, Meliponinae): floral preferences, Apidologie 20, 185-195.

Ramalho M., Kleinert-Giovannini A., ImperatrizFonseca V.L. (1990) Important bee plants for stingless bees (Melipona and Trigonini) and Africanised honeybees (Apis mellifera) in neotropical habitats: a review, Apidologie 21, 469-488.

Ranger S., O'Donnell S. (1999) Genotypic effects on forager behavior in the neotropical stingless bee Partamona bilineata (Hymenoptera: Meliponidae), Naturwissenschaften 86, 187-190.

Robinson G.E. (1987) Regulation of honey bee age polyethism by juvenile hormone, Behav. Ecol. Sociobiol. 20, 329-338.

Roubik D.W. (1978) Competitive interactions between neotropical pollinators and africanized honey bees, Science 201, 1030-1032.

Roubik D.W. (1980) Foraging behaviour of competing Africanized honey bees and stingless bees, Ecol. 61, 836-845.

Roubik D.W. (1983a) Experimental community studies: Time-series tests of competition between
African and Neotropical bees, Ecology 64, 971978.

Roubik D.W. (1983b) Nest and colony characteristics of stingless bees from Panama (Hymenoptera: Apidae), J. Kans. Entomol. Soc. 56, 327-355.

Roubik D.W. (1989) Ecology and Natural History of Tropical Bees, Cambridge University Press, New York.

Roubik D.W. (1992) Stingless bees: a guide to Panamanian and Mesoamerican species and their nests (Hymenoptera: Apidae: Meliponinae), in: Quintero D., Aiello A. (Eds.), Insects of Panamá and Mesoamerica, Oxford University Press, Oxford, pp. 495-524.

Roubik D.W., Buchmann S.L. (1984) Nectar selection by Melipona and Apis mellifera (Hymenoptera: Apidae) and the ecology of nectar intake by bee colonies in a tropical forest, Oecologia 61, $1-10$.

Roubik D.W., Moreno J.E. (2000) Pollen specialization and generalization by stingless bees (Apidae: Meliponini), in: IBRA (Ed.), Proc. 6th Int. Conf. Apiculture in Tropical Climates, IBRA, Cardiff, pp. 112-118.

Roubik D.W., Wolda H. (2001) Do competing honey bees matter? Dynamics and abundance of native bees before and after honey bee invasion, Popul. Ecol. 43, 53-62.

Roubik D.W., Moreno J.E., Vergara C., Wittmann D. (1986) Sporadic food competition with the African honeybee: projected impact on neotropical stingless bees, J. Trop. Ecol. 2, 97-111.

Roubik D.W., Smith B.H., Carlson R.G. (1987) Formic acid in caustic cephalic secretions of stingless bee, Oxytrigona (Hymenoptera: Apidae), J. Chem. Ecol. 13, 1079-1086.

Roubik D.W., Yanega D., Aluja S.M., Buchmann S.L., Inouye D.W. (1995) On optimal nectar foraging by some tropical bees (Hymenoptera: Apidae), Apidologie 26, 197-211.

Schmidt V.M., Zucchi R., Barth F.G. (2003) A stingless bee marks the feeding site in addition to the scent path (Scaptotrigona aff. depilis), Apidologie 34, 237-248.

Schwarz H.F. (1932) Stingless bees in combat, Nat. Hist. 32, 552-553.

Seeley T.D. (1983) Division of labour between scouts and recruits in honeybee foraging, Behav. Ecol. Sociobiol. 12, 253-259.

Seeley T.D. (1995) The wisdom of the hive, Harvard University Press, Cambridge, Massachusetts.

Seeley T.D., Visscher P.K. (1988) Assessing the benefits of cooperation in honeybee foraging: search costs, forage quality, and competitive ability, Behav. Ecol. Sociobiol. 22, 229-237.

Seeley T.D., Kühnholz S., Weidenmüller A. (1996) The honey bee's tremble dance stimulates additional bees to function as nectar receivers, Behav. Ecol. Sociobiol. 28, 277-290.

Slaa E.J. (2003) Foraging ecology of stingless bees: from individual behaviour to community 
ecology, Dissertation Utrecht University, The Netherlands.

Slaa E.J., Cevaal A., Sommeijer M.J. (1998) Flower constancy in Trigona stingless bees foraging on artificial flower patches: a comparative study, J. Apic. Res. 37, 191-198.

Slaa E.J., Tack A., Sommeijer M.J. (2003a) The effect of intrinsic and extrinsic factors on flower constancy in stingless bees, Apidologie 34, 457468.

Slaa E.J., Wassenberg J., Biesmeijer J.C. (2003b) The use of field-based social information in eusocial foragers: local enhancement among nestmates and heterospecifics in stingless bees, Ecol. Entomol. 28, 369-379.

Sommeijer M.J. (1984) Distribution of labor among workers of Melipona favosa F.: age-polyethism and worker oviposition, Insectes Soc. 31, 171184.

Sommeijer M.J., Beuvens F.T., Verbeek H.J. (1982) Distribution of labour among workers of Melipona favosa: construction and provisioning of brood cells, Insectes Soc. 29, 222237.

Sommeijer M.J., de Rooy G.A., Punt W., de Bruijn L.L.M. (1983) A comparative study of foraging behavior and pollen resources of various stingless bees (Hym., Meliponinae) and honeybees (Hym.,
Apinae) in Trinidad, West-Indies, Apidologie 14, 205-224.

Sommeijer M.J., de Bruijn L.L.M., van der Guchte C. (1985) The social food-flow within the colony of a stingless bee Melipona favosa (F.), Behaviour 92, 39-58.

Spaethe J., Weidenmüller A. (2002) Size variation and foraging rate in bumblebees (Bombus terrestris), Insectes Soc. 49, 142-146.

Spaethe J., Tautz J., Chittka L. (2001) Visual constraints in foraging bumblebees: flower size and color affect search time and flight behavior, Proc. Natl. Acad. Sci. 98, 3898-3903.

Suka T., Inoue T. (1993) Nestmate recognition of the stingless bee Trigona (Tetragonula) minangkabau, J. Ethol. 11, 141-147.

Theraulaz G., Bonabeau E. (1995) Coordination in distributed building, Science 269, 686-688.

Thierry B., Theraulaz G., Gautier J.Y., Stiegler B. (1996) Joint memory, Behav. Proc. 35, 127-140.

Thorpe W.H. (1956) Learning and instinct in animals, Methuen and Co., London.

Villa J.D., Weiss M.R. (1990) Observations on the use of visual and olfactory cues by Trigona spp. foragers, Apidologie 21, 541-545.

Wenner A.M., Johnson D.L. (1966) Simple conditioning in honeybees, Anim. Behav. 14, 149-155. 